\title{
A Potential Application of Endophytic Bacteria in Strawberry Production
}

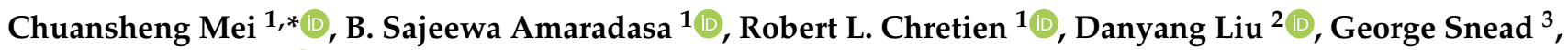 \\ Jayesh B. Samtani ${ }^{2}$ (D) and Scott Lowman ${ }^{1}$ \\ 1 The Plant Endophyte Research Center, The Institute for Advanced Learning and Research, \\ Danville, VA 24540, USA; Sajeewa.Amaradasa@ialr.org (B.S.A.); Robert.Chretien@ialr.org (R.L.C.); \\ scott.lowman@ialr.org (S.L.) \\ 2 Hampton Roads Agricultural Research and Extension Center, School of Plant and Environmental Sciences, \\ Virginia Tech, Virginia Beach, VA 23455, USA; dadanyan@vt.edu (D.L.); jsamtani@vt.edu (J.B.S.) \\ 3 Braehead Farm, Fredericksburg, VA 22401, USA; braeheadstrawberries@gmail.com \\ * Correspondence: chuansheng.mei@ialr.org; Tel.: +1-434-766-6704
}

Citation: Mei, C.; Amaradasa, B.S. Chretien, R.L.; Liu, D.; Snead, G.; Samtani, J.B.; Lowman, S. A Potential Application of Endophytic Bacteria in Strawberry Production. Horticulturae 2021, 7, 504. https://doi.org/ $10.3390 /$ horticulturae 7110504

Academic Editor: Esmaeil Fallahi

Received: 1 October 2021

Accepted: 16 November 2021

Published: 18 November 2021

Publisher's Note: MDPI stays neutral with regard to jurisdictional claims in published maps and institutional affiliations.

Copyright: () 2021 by the authors. Licensee MDPI, Basel, Switzerland. This article is an open access article distributed under the terms and conditions of the Creative Commons Attribution (CC BY) license (https:// creativecommons.org/licenses/by/ $4.0 /)$.

\begin{abstract}
Endophytic bacteria could be used as a tool to promote plant growth, enhance abiotic stress tolerance, and inhibit plant pathogen growth. More than 100 bacteria, previously tested to have biocontrol activity against fungal pathogens from our lab, were chosen for pathogen inhibition in vitro with antibiosis assays against strawberry specific pathogens. Three potential endophytic bacteria were tested in the greenhouse for disease reduction and growth performance. Finally, field trials were conducted for fruit yield production. Our results showed that three endophytic bacteria significantly inhibited the growth of the strawberry pathogen Colletotrichum gloeosporioides from antibiosis assays and were identified as Bacillus velezensis strains IALR308, IALR585, and IALR619. Inoculation of these bacteria significantly reduced strawberry disease in greenhouse conditions with pathogen infection. Field trials showed that IALR619 has potential to influence marketable fruit yield when strawberry plants were inoculated twice over the growing season. All three bacteria had the ability to produce auxin and to solubilize phosphate. The antibiotics surfactin and iturin were also detected in IALR585 and IALR619. In conclusion, Bacillus velezensis IALR619 has potential inhibition of strawberry pathogen growth in the greenhouse and possible ability to increase marketable fruit yield in the field.
\end{abstract}

Keywords: endophytic bacteria; Bacillus velezensis; biological control; strawberry; field trials

\section{Introduction}

Strawberry (Fragaria $\times$ ananassa) is one of the most favorite fruits in the U.S. An average American consumes around $3.2 \mathrm{~kg}$ of strawberry every year [1]. There is potential to increase strawberry production in the U.S. due to increasing consumer demand and interest in fresh and local strawberries, and small-scale strawberry acreage is expected to increase to meet these demands [2]. However, the long-term sustainability and viability of the strawberry industry depends on overcoming many challenges. A primary challenge in strawberry production is to find alternative solutions to methyl bromide fumigation, which is currently only allowed as a fumigant in strawberry nurseries under critical use exemption. Research study has shown that loss of methyl bromide for fumigation in the field could result in strawberry yield reduction up to $15 \%$ and an increase in pest pressure from early season weed competition and diseases such as anthracnose (Colletotrichum spp.) and grey mold (Botrytis spp.) [2,3]. Colletotrichum acutatum and C. gloeosporioides have consistently been identified as the most destructive pathogens in the mid-South region of the U.S. [2]. About half of the commercial strawberry growers in Virginia no longer fumigate [4]. Plant growth-promoting bacteria (including rhizospheric and endophytic) can promote plant growth, enhance abiotic stress tolerance, and inhibit pathogen growth [5-7]. 
There are many biostimulants and biocontrol agents commercially available. Endophytic bacteria, in particular, have many advantages. Host plants provide the habitat and nutrients to their endophytic bacteria without detrimental impact to the host plants. In return endophytic bacteria enhance the plant adaptation and growth in soil through plant growth hormone production and nutrient acquisition, while reducing the environmental impacts of agriculture [8-10]. However, there are relatively fewer studies on strawberry production with limited applications in the field. For instance, Kim et al. used formulated Bacillus licheniformis $\mathrm{N} 1$ to control Botrytis cinerea in pot experiments, plastic house, and field conditions. They showed that $B$. licheniformis N1 could prevent gray mold disease, before fungal infection, with three applications at one-week intervals [11]. Tortora et al. reported that in growth chamber experiments, siderophore-producing bacterium Azospirillum brasilense inhibited strawberry anthracnose caused by the fungus $C$. acutatum and could be used as a biocontrol agent in strawberry production [12]. Cha et al. isolated potential bacteria from strawberry fields and found that Streptomyces sp. S4-7 significantly reduced Fusarium wilt in growth chamber and commercial field studies [13]. Additionally, Todeschini et al. found that plant growth-promoting bacterium Pseudomonas fluorescens strain Pf4 increased strawberry flower and fruit production with improved quality in greenhouse experiments [14]. Recently, de Andrade et al. observed that a combination of three bacteria (Azospirillum brasilense Ab-V, Burkholderia cepacia CCMA 005, and Enterobacter cloacae CCMA 1285) significantly promoted strawberry growth compared with non-inoculated control under $50 \%$ of the recommended nitrogen application [15].

As next-generation sequencing technology has dramatically advanced, bacterial genomic sequences have easily and quickly been achieved. From genome sequences, Chen et al. characterized the giant modular polyketide synthase gene clusters, which are responsible for the biosynthesis of the antibiotics bacillaene and difficidin or oxydifficidin in B. amyloliquefaciens [16]. Cha et al. predicted that Streptomyces sp. S4-7 produced a novel ribosomally synthesized thiopeptide to suppress Fusarium wilt of strawberry caused by F. oxysporum [13].

The objectives of this study were (i) to screen endophytic bacteria from our endophytic bacteria library against strawberry pathogens in vitro, (ii) to test potential endophytic bacteria for reducing strawberry crown rot caused by Colletotrichum gloeosporioides and for promoting plant growth in the greenhouse, (iii) to conduct endophytic bacterial inoculation in strawberry fields to evaluate strawberry growth and fruit production, as well as note any disease incidence observed in the field, and (iv) to elucidate the mechanisms of fungal pathogen inhibition by these bacteria with genome sequence analysis.

\section{Materials and Methods}

\subsection{Plant Materials and Endophytic Bacteria}

Strawberry (Fragaria $\times$ ananassa) $\mathrm{cv}$. Chandler plug plants were purchased from Aaron's Creek nursery in Buffalo Junction, Virginia, USA for greenhouse experiments and field trials. Endophytic bacteria were isolated from plants grown in the foothills of the Appalachian Mountains in Central Virginia, USA (geographic location: 37.125372, $-79.298415)$. The soil was not fertilized. Healthy plants were selected randomly from the natural environment. Plants were taken from the field and brought to the lab for endophytic bacterial isolation or kept in a refrigerator temporarily. Once endophytic bacteria were isolated from leaf, stem or root tissues and grown on Luria-Bertani (LB) with $15 \mathrm{~g} / \mathrm{L}$ agar, glycerol stocks were made for long-term storage at $-80^{\circ} \mathrm{C}$ in the Plant Endophyte Research Center at the Institute for Advanced Learning and Research in Danville, Virginia, USA. Routine bacterial growth and culture followed the procedures reported previously $[17,18]$.

\subsection{In Vitro Antifungal Screening}

The antibiosis test was conducted on $100 \mathrm{~mm}$ PDA plates containing $25 \mathrm{~mL}$ of medium. One $8 \mathrm{~mm}$ diameter hole was created at the edge of the PDA plate and filled with melted half-strength LB with $15 \mathrm{~g} / \mathrm{L}$ agar. Overnight bacterial cultures $(2.5 \mu \mathrm{L})$ were applied to 
the solidified LB disc. Plates were incubated at $28{ }^{\circ} \mathrm{C}$ for $24 \mathrm{~h}$. The next day, an $8 \mathrm{~mm}$ disc was then taken from a PDA plate containing pathogen Colletotrichum gloeosporioides Cg58 and placed on the opposite side of the PDA plate, equally distant from the plate edge. The plates were then incubated at $28^{\circ} \mathrm{C}$ until the fungus grew to the other side of the control bacterium ( $\sim 3$ weeks) without biocontrol activity (IALR582). The formula for pathogen inhibition is: \% Inhibition $=[$ (Radius of mycelial mat with control plug - Radius of mycelial mat with endophyte disc)]/(radius of the control) $\times 100$.

\subsection{Plant Growth-Promoting Traits \\ 2.3.1. Auxin Quantification}

The auxin quantification was modified from Patten and Glick's protocol [19] following our previous publication [17] using Salkowski reagent in triplicate for each bacterium. Indole acetic acid (IAA) was used for a standard curve. The auxin concentration was expressed as $\mu \mathrm{g} / \mathrm{mL}$ bacterial culture.

\subsubsection{Phosphate Solubilizing Ability}

Selected bacteria were tested for phosphate solubilizing ability following our previous protocol [17]. Briefly, the overnight bacterial culture $(0.1 \mathrm{~mL})$ was added to $3.9 \mathrm{~mL}$ of NBRIP containing $0.5 \%$ of tricalcium phosphate (in triplicate for each) and incubated at $28^{\circ} \mathrm{C}$ with shaking at $200 \mathrm{rpm}$ for 3 days. One $\mathrm{ml}$ of bacterial culture was centrifuged at $14,000 \mathrm{rpm}$ for $10 \mathrm{~min}$, and the soluble phosphorus in the supernatant was determined following the method of Murphy and Riley [20]. The amount of soluble phosphorus was calculated from the standard curve of $\mathrm{P}$ concentration using $\mathrm{KH}_{2} \mathrm{PO}_{4}$.

\subsubsection{Nitrogen Fixation and ACC Deaminase Activity Screening and Siderophore Production}

Selected bacteria were also screened for nitrogen fixation and ACC deaminase activity, and tested for siderophore production following our previous protocol [17].

\subsection{Greenhouse Experiments}

After in vitro screening, three bacterial strains (IALR308, IALR585, and IALR619) showing $>50 \%$ pathogen growth inhibition in vitro were chosen to do greenhouse experiments for disease reduction and growth promotion with plug strawberry cv. Chandler. A complete randomized block design was used with 3 replicates and 5 plants per replicate. The bacteria were grown in full strength LB medium (Lennox) based on manufacturer IBI Scientific (Dubuque, IA, USA) until the $\mathrm{OD}_{600}$ reached about 2.0. The bacterial culture was then diluted with an equal amount of deionized water, and the plants were soaked in the bacterial culture $\left(\mathrm{OD}_{600}=1.0\right)$ for $2 \mathrm{~h}$. The plants were then transplanted to plastic pots $(\varnothing 15.24 \mathrm{~cm})$ filled with Sungro Professional Growing Mix (Sungro Horticulture) and grown in the greenhouse. For the control, full strength LB was diluted with an equal amount of deionized water. After two weeks, the pathogen was applied to the base of each plant using $1 \mathrm{~mL}$ of spore solution $\left(\sim 5 \times 10^{5}\right.$ spores $\left./ \mathrm{mL}\right)$. After a month, the plants were fed weekly with a 20-20-20 fertilizer $(1 \mathrm{~g} / \mathrm{L})$. Dead plants were recorded every week and the fresh weight of the shoots and roots was recorded at the end of experiment.

\subsection{Fruit Yields in the Field Trials}

The field trials were conducted in 2018-2019 and 2019-2020 growing seasons. For the 2018-2019 trial, a randomized complete block design was conducted with triplicates at three farms in Virginia, USA. The locations were the City of Chesapeake, the City of Fredericksburg, and one in Buffalo Junction (Mecklenburg County). The field trials consisted of 5 treatments: IALR308, IALR585, IALR619, all three bacteria, and control. The plug plants were inoculated by soaking in above treatment solution in a half-strength LB medium overnight before transplanting. For the control, plug plants were soaked in a half-strength LB medium. Preplant fertilizers were added to the strawberry beds based on recommendations of the Virginia Tech soil testing laboratory. All replicates had 
twelve plants of 'Chandler' that were in two-row beds spaced $35 \mathrm{~cm}$ apart in a staggered manner. Plug plants were inoculated with bacterial cultures on 9 October 2018 for the City of Fredericksburg, on 3 October 2018 for the City of Chesapeake, and 25 October 2018 for Buffalo Junction. All inoculated plug plants were transplanted next day and production practices were as per grower standards. Depending on the grower's location, berries were harvested once or twice per week and separated into marketable and non-marketable categories. Non-marketable fruits consisted of diseased, rotten, misshapen, animal/insect damaged, or small fruits ( $<10 \mathrm{~g}$ fruit weight).

For the 2019-2020 growing season, two field trials were conducted in a research field at the Hampton Roads AREC in Virginia Beach and in the City of Fredericksburg, VA. The study was a randomized complete block design and limited to testing the best performing bacterial strain, i.e., IALR619 from previous field trials. The treatments consisted of (i) an untreated control, (ii) plants inoculated with IALR619 strain before transplanting, and (iii) plants inoculated with IALR619 before transplanting and followed up with a drench application of $50 \mathrm{~mL}$ bacterial solution per plant in the spring season. Plug plants were inoculated on 10 September 2019 for the City of Fredericksburg and on 18 September 2019 for the Hampton Roads AREC and transplanted next day. Spring application were conducted on 2 April 2020 for both sites. Strawberry fruits were collected twice per week and graded as described in the 2019 harvest season.

\subsection{Genomic Sequencing and Analysis and Phylogenic Tree Construction}

Based on in vitro screening, the three bacterial strains showing strong pathogen inhibition were selected for identification with $16 S$ rRNA gene sequencing by Genewiz Company (South Plainfield, NJ, USA). Further characterization was done by whole genome sequencing with an Illumina MiSeq next-generation sequencer according to the manufacturer's protocol. Briefly, genomic DNA was extracted from bacterial cultures using a PureLinkTM Genomic DNA Mini Kit (Invitrogen, Waltham, MA, USA) according to the manufacturer's instructions. Genome sequencing was carried out in an Illumina MiSeq next-generation sequencer which generated $150 \mathrm{bp}$ paired-end reads. The quality of the FASTQ shorts reads was examined using FastQC software (http: / / www.bioinformatics. babraham.ac.uk/projects / fastqc/ (accessed on 2 September 2021)), and adapters and low quality leading and trailing bases were removed using the Trimmomatic trimming tool [21]. The reads were assembled de novo using the Velvet algorithm [22]. Different k-mer values were tested, and k-mer 63 was used to get the best assembly. For better species-level identification, assembled contigs were uploaded to the KmerFinder webpage maintained by the Center for Genomic Epidemiology of Technical University of Denmark (DTU) (http:/ / cge.cbs.dtu.dk/services/KmerFinder/ (accessed on 2 September 2021)). Since IALR619 performed better than the other two strains, its genomic characterization was further performed as follows. Microbial gene prediction tool Prodigal [23] was used to identify protein-coding genes of the strain. Barrnap 0.8 (https:/ / github.com/tseemann/barrnap (accessed on 2 September 2021)), which is a ribosomal RNA gene prediction tool and tRNAscan-SE v2.0 [24], a transfer RNA prediction tool, were used to further decipher non-coding RNA family genes of this strain. The contigs generated from the Velvet algorithm were ordered against a closely related reference genome from GenBank using the 'Move Contigs' option available in Mauve software (http:/ / asap.ahabs.wisc.edu/mauve/ (accessed on 2 September 2021)) [25]. The ordered contigs were annotated using the RAST server (http: / / rast.nmpdr.org / (accessed on 2 September 2021)) [26].

Since whole-genome sequencing was performed for all three bacteria and phylogenetic inference using multiple orthologous genes is far better than using a single 16S rRNA gene, we used the former method for tree construction. The protein-coding genes derived from IALR308, IALR585, and IALR619 were used for phylogenetic orthology inference and subsequent building of a species tree. The reference proteomes included $B$. velezensis strains FZB42 (NC_009725.1) and M75 (NZ_CP016395.1); B. amyloliquefaciens strains DSM7 (NC_014551.1) and MT45 (NZ_CP011252.1); and an outgroup B. subtilis 168 (NC_000964.3). 
OrthoFinder software was used to derive 1:1 orthologs (single-copy genes) for all strains in the analysis [27]. The tree has been inferred using the STAG algorithm [28] and rooted using the STRIDE algorithm [29].

\subsection{Quantification of Antibiotic Compounds Produced by Bacterial Endophytes}

The $0.5 \mathrm{~mL}$ of overnight bacterial culture was inoculated to $25 \mathrm{~mL}$ of LB medium in $125 \mathrm{~mL}$ sterile flasks and grown in a $28^{\circ} \mathrm{C}$ shaker with $200 \mathrm{rpm}$ for 4 days. One $\mathrm{ml}$ of bacterial culture was centrifuged at $14,000 \mathrm{rpm}$ for $10 \mathrm{~min}$. The supernatant was diluted 100 times and analyzed on a Waters I-class UPLC coupled with a TQXS Mass Spectrometer. Separation was accomplished using a Waters CORTECS column under reversed-phase conditions. The gradient elution was carried out using different organic modifiers (methanol and acetonitrile). Formic acid was used as an additive for achieving optimal ionization under electrospray conditions as well as achieving Gaussian peak shape for the chromatography. Mass spectrometry was used in the detection and quantitation of surfactin and iturin (Sigma-Aldrich, St. Louis, MO, USA). Surfactin was analyzed in MRM mode using $m / z$ transitions $1036.5>685.4$ and $1036.5>227.1$. Iturin was analyzed in SIR mode under the $\mathrm{m} / \mathrm{z}$ of 1058 . Under the employed chromatographic conditions, surfactin elutes at $4.15 \mathrm{~min}$ and iturin elutes at $0.59 \mathrm{~min}$.

\subsection{Statistical Analysis}

Percentage data for anthracnose disease reduction in greenhouse experiments were converted using arcsine transformation. Data for disease reduction and growth promotion in greenhouse experiments were subjected to an analysis of variance (ANOVA model I), and Fisher's LSD (the least significant difference) was used for multiple treatment comparison using SAS ${ }^{\circledR}$ Studio from SAS OnDemand for Academics. Field fruit data were analyzed using SAS v. 9.4 using a one-way ANOVA and means separated by LSD at alpha $=0.05$.

\section{Results}

\subsection{Origination and Identification of Potential Endophytic Bacteria}

Based on our preliminary results for fungal pathogen growth inhibition and $16 S$ rRNA sequences, three potential bacterial endophytes were chosen for further study. The information of origination, species identification, and the accession numbers in GenBank for bacterial 16S rRNA sequences are listed in Table 1.

Table 1. Origination and identification of the bacterial endophytes.

\begin{tabular}{ccccc}
\hline Strains & Species & Accession Number & Tissues & Plants \\
\hline IALR308 & Bacillusvelezensis & OK584762 & Shoot & Vitis spp. \\
IALR585 & Bacillus velezensis & OK584763 & Shoot & Trifolium repens \\
IALR619 & Bacillus velezensis & OK584764 & Leaf & Salix atrocinerea \\
\hline
\end{tabular}

\subsection{Screening Endophytic Bacteria against Strawberry Pathogen Growth in Plate Assay}

More than 100 bacterial strains capable of inhibiting other fungal pathogens had been selected from our bacterial endophyte library in preliminary experiments. We then screened these bacteria against the strawberry pathogen C. gloeosporioides Cg58. Three bacterial strains showed strong inhibition of pathogen growth with a clear inhibition zone, compared with the control bacterium IALR582 with no antibiotic activity (Figure 1). The inhibition was 50\%, 50\% and 52\% for IALR308, IALR585 and IALR619, respectively. 


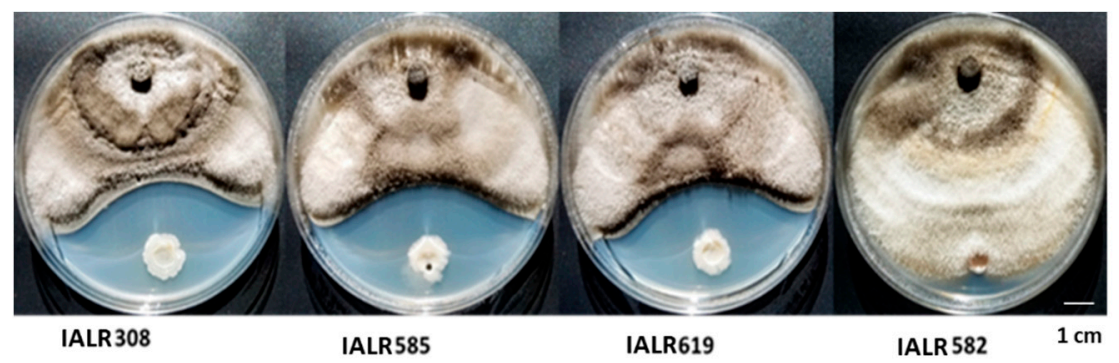

Figure 1. Endophytic bacterial inhibition of strawberry fungal pathogen C. gloeosporioides Cg58. The fungal pathogen was grown at $30{ }^{\circ} \mathrm{C}$ from 23 December 2020 to 13 January 2021.

\subsection{Plant Growth-Promoting Traits of Endophytic Bacteria}

These three endophytic bacteria were also characterized for their plant growthpromoting traits. All three bacteria have the ability to produce the plant hormone auxin and to solubilize insoluble phosphate (Table 2) although the activity is low compared to other bacteria in our library [17]. However, they do not produce siderophore compounds, fix nitrogen from the atmosphere or have ACC deaminase activity (data not shown).

Table 2. Plant growth-promoting traits of selected bacterial endophytes.

\begin{tabular}{cccc}
\hline Traits & $\begin{array}{c}\text { Bacillus } \\
\text { velezensis IALR308 }\end{array}$ & $\begin{array}{c}\text { Bacillus } \\
\text { velezensis IALR585 }\end{array}$ & $\begin{array}{c}\text { Bacillus } \\
\text { velezensis IALR619 }\end{array}$ \\
\hline Auxin $(\mu \mathrm{g} / \mathrm{mL})$ & $9.6 \pm 0.8$ & $6.7 \pm 0.6$ & $7.5 \pm 0.1$ \\
P content $(\mu \mathrm{g} / \mathrm{mL})$ & $20.4 \pm 3.3$ & $16.0 \pm 0.1$ & $15.3 \pm 2.4$ \\
\hline
\end{tabular}

Note: Data were means of 3 replicates \pm standard errors and calculated by subtracting baseline data in a sterile medium. Bacterial cultures were grown at $28^{\circ} \mathrm{C}$ for 3 days with shaking at $200 \mathrm{rpm}$.

\subsection{Disease Reduction in the Greenhouse Test}

The three best bacterial strains with different combinations were tested for disease reduction with pathogen infection in the greenhouse. Average mortality rates were significantly reduced by inoculation of IALR619 and 3 bacterial combinations compared with non-inoculated control (Figure 2).

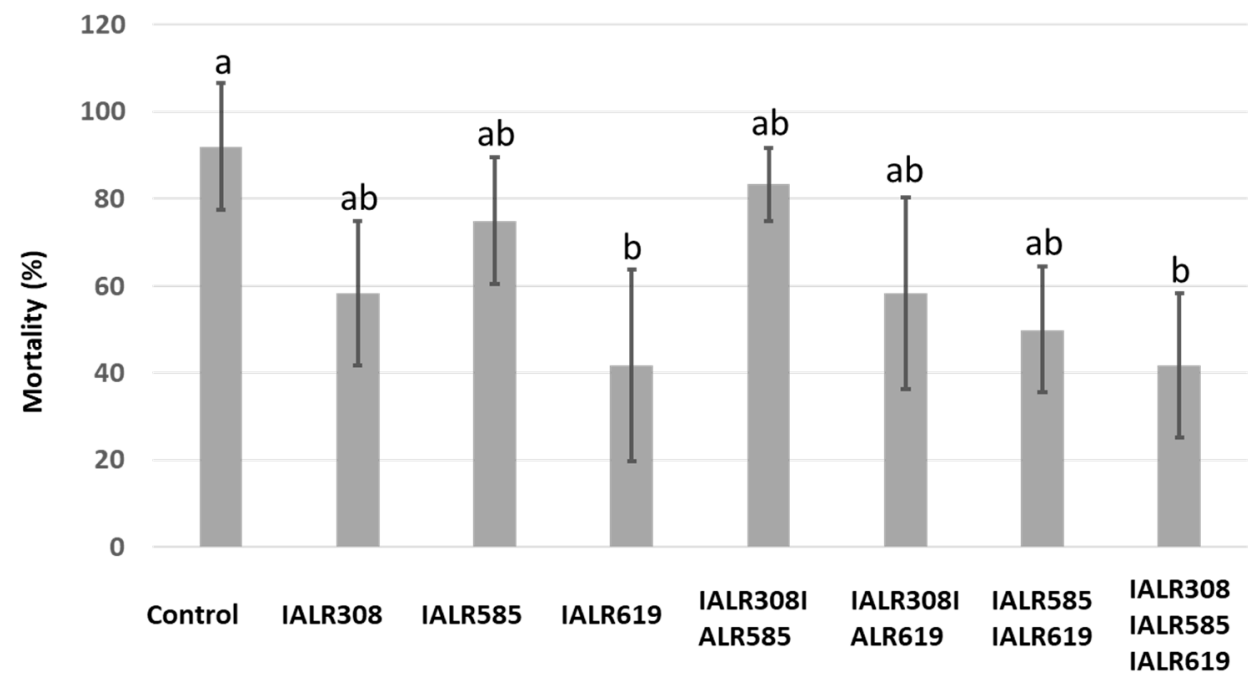

Figure 2. Effects of bacterial inoculation on average strawberry mortality in the greenhouse. Different letters on bars mean significantly different at $p<0.05$. The Fisher's LSD test was used for comparing differences between treatment means. Plug strawberry plants were inoculated with bacterial cultures on 20 September 2018 and infected with fungal pathogen on 3 October 2018. Final mortality was recorded on 31 January 2019. 


\subsection{Growth Promotion in the Greenhouse Experiments}

The endophytic bacteria were tested for strawberry plant growth performance in the greenhouse. Average root fresh weights of IALR585, IALR619, and IALR585/619 treatments were $64 \%, 61 \%$, and $73 \%$ higher than non-inoculated control, respectively (Figure 3). Among treatments, only IALR585 and IALR585/619 treatments significantly increased average root fresh weight over control. There were no significant differences between bacterial treatments and control in average shoot fresh weight.

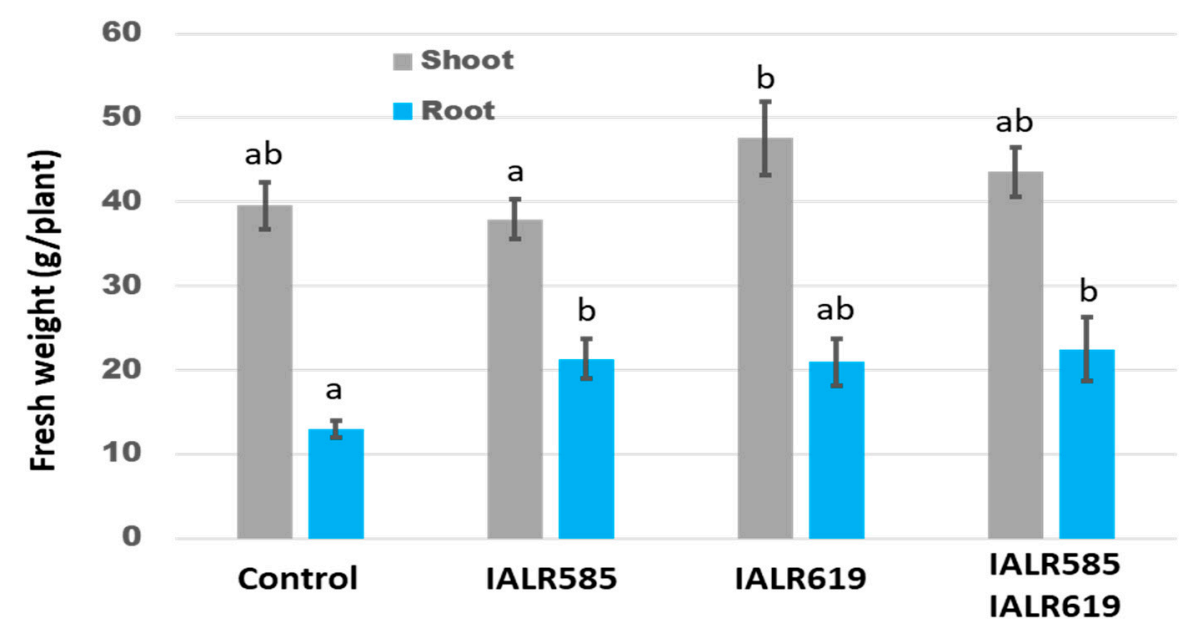

Figure 3. Effects of bacterial inoculation on strawberry shoot and root growth in the greenhouse. Different letters on bars mean significantly different at $p<0.05$. The Fisher's LSD test was used for comparing differences between treatment means. Plug strawberry plants were inoculated with bacterial cultures on 3 May 2018 and fresh weights were recorded on 9 August 2018.

\subsection{Field Trials in Different Locations}

For the 2018-2019 growing season, there were no statistical differences between bacterial treatments and control on marketable yield at all three locations. Based on the preliminary results obtained in the 2018-2019 growing season with possible benefits of IALR application in the field, for the 2019-2020 growing season, we focused on IALR619 strain in the field trials with three treatments: one application in fall, two applications in fall and spring, and an untreated control. At the location in the City of Fredericksburg, application of IALR619 in both fall and spring significantly increased marketable yield over non-treated control. Marketable yield was $21 \%$ higher in B. velezensis IALR619 treatment applied both in fall and spring than that of non-treated control (Table 3). At the Hampton Roads AREC, there were no significant differences between bacterial treatments and control.

Table 3. Effects of bacterial application on strawberry yield.

\begin{tabular}{cccc}
\hline Treatments & Marketable Yield & Non-Marketable Yield & Total Yield \\
\hline IALR619 (Fall + Spring) & $519.6 \mathrm{~b}^{*}$ & 144.2 & 663.8 \\
IALR619 (Fall) & $463.2 \mathrm{ab}$ & 145.5 & 608.7 \\
Non-treated control & $429.8 \mathrm{a}$ & 155.5 & 585.2 \\
\hline$p$-value & 0.0425 & 0.1425 & 0.0655 \\
\hline
\end{tabular}

${ }^{*}$ Means with same letter within a column are not significantly different at $p<0.05$. Data were sum of cumulative season yield (g/plant) in Fredericksburg, VA, USA during the 2019-2020 growing season.

\subsection{Genome Sequence Analysis of IALR619 Strain and Phylogenetic Tree}

A total of 3,275,370 raw reads were assembled by Velvet in producing the assembly. More details of the assembly are given in Table 4. 
Table 4. Genomic features of Bacillus velezensis IALR619.

\begin{tabular}{ll}
\hline Features & Value \\
\hline Gene total length (bp) & $3,871,487$ \\
Maximum contig length (bp) & $1,068,237$ \\
N50 (bp) & $1,020,364$ \\
Depth of genome coverage & 67 \\
Gene average length (bp) & 101,881 \\
Chromosome number & 1 \\
GC content in gene region (\%) & 46.6 \\
Protein-coding genes (CDSs) & 3783 \\
rRNA genes & 4 \\
tRNA genes & 66 \\
\hline
\end{tabular}

All three bacterial strains were identified as B. velezensis species based on $16 \mathrm{~S}$ rRNA sequence analysis using the BLAST tool on the NCBI database. The species identification was further confirmed when de novo assemblies were uploaded to the DTU website (http://cge.cbs.dtu.dk/services/KmerFinder/ (accessed on 2 September 2021)). The consensus phylogenetic tree for species deciphered from single-copy gene trees was given in Figure 4. Our bacteria were very closed to B. velezensis M75, which was reported to have strong antagonistic activity towards fungal plant pathogens [30].

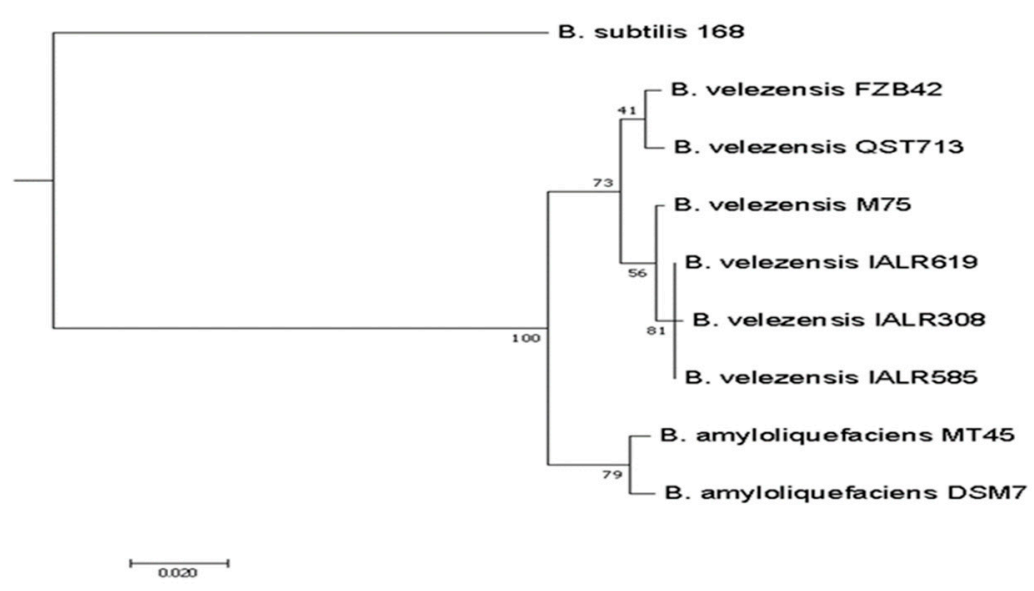

Figure 4. Phylogenetic tree based on the proteomes of IALR308, IALR585, and IALR619. These isolates grouped closely to reference Bacillus velezensis M75. The tree has been rooted using the outgroup B. subtilis 168. The reference proteomes included B. velezensis FZB42 (NC_009725.1), B. velezensis M75 (NZ_CP016395.1), B. velezensis QTS713 (NZ_CP025079), B. amyloliquefaciens DSM7 (NC_014551.1), B. amyloliquefaciens MT45 (NZ_CP011252.1), and outgroup B. subtilis 168 (NC_000964.3).

\subsection{Antibiotic Compounds Produced by Endophytic Bacteria}

Two antibiotic compounds were detected in bacterial cultures of strains IALR585 and IALR619 with standard surfactin and iturin, but not in strain IALR308 culture (Table 5).

Table 5. Surfactin and iturin production in cultures of bacterial endophytes.

\begin{tabular}{cccc}
\hline $\begin{array}{c}\text { Antibiotics } \\
(\mu \mathrm{g} / \mathrm{mL})\end{array}$ & $\begin{array}{c}\text { Bacillus velezensis } \\
\text { IALR308 }\end{array}$ & $\begin{array}{c}\text { Bacillus } \\
\text { velezensis IALR585 }\end{array}$ & $\begin{array}{c}\text { Bacillus } \\
\text { velezensis IALR619 }\end{array}$ \\
\hline Surfactin & ND & $80.2 \pm 7.9$ & $39.5 \pm 2.2$ \\
Iturin & ND & $206.8 \pm 8.7$ & $33.2 \pm 0.7$ \\
\hline
\end{tabular}

Note: ND means these compounds could not be detected in given conditions. Bacteria were grown in a $28^{\circ} \mathrm{C}$ shaker with $200 \mathrm{rpm}$ for 4 days. 


\section{Discussion}

Research on selecting biocontrol agents in strawberry production has received much attention because biocontrol agents come from natural resources and are environmentally friendly. Moreover, some biocontrol agents have plant growth promotion abilities. Several studies reported that beneficial fungi and bacteria could effectively control or reduce strawberry diseases [12,31-33]. However, this area is still in its infancy and much of the work is limited to the lab and the greenhouse. In this study, we screened our endophytic bacterial library against strawberry pathogen C. gloeosporioides Cg58 in plate assays and found that three $B$. velezensis strains significantly inhibited pathogen growth (Figure 1). In the greenhouse experiments with pathogen infection, the IALR619 and 3 bacterial combinations treatments showed a reduction of disease rate (Figure 2), and the IALR585 and IALR585/IALR619 treatments promoted root growth as well (Figure 3). In the first year field trials, we did see an endophyte effect on marketable yield. In the second year field trials at one location, B. velezensis IALR619 (applied twice over the season) significantly increased marketable fruit yield by $21 \%$, compared with non-treated control (Table 3). However, there were no differences between bacterial treatments and control in total fruit yields, probably due to a slightly higher non-marketable yield in control treatment. Similar results were reported by Pastrana et al. (2016) with two commercial products (Prodigy ${ }^{\circledR}$ containing Trichoderma asperellum T18 strain and Fusbact ${ }^{\circledR}$ containing Bacillus megaterium and B. laterosporus) [31]. Although one product Prodigy ${ }^{\circledR}$ significantly prevented crown necrosis and increased average strawberry fruit yield, there were no significant differences in average fruit yield between inoculated and non-inoculated control [31]. Todeschini et al. (2018) conducted the combination of AM fungi and Pseudomonads bacteria in strawberry production, and results showed that some combinations could significantly increase root dry weight, but no significant increase in average fruit weight per plant between control and any inoculation treatments [14]. However, combination of AM fungi and Pseudomonads could increase fruit production and vitamin contents in strawberry grown in low nitrogen and phosphorus levels [34]. Nam et al. (2009) also reported that the inoculation of $B$. velezensis BS87 or RK1 had greater fresh weight of fruits compared with non-inoculated control, with only BS87 having significant difference from control in the 2003-2004 growing season, but no significant differences between bacterial treatments and control in the 2004-2005 growing season [35]. From our study, we believe the ability of IALR619 to produce auxin and to solubilize phosphate could result in enhanced root growth and nutrient acquisition. Therefore, multiple applications of bacterial inoculants in the field may be responsible for the increase in fruit yield (Table 2). No major outbreaks with crown rot or fruit rot incidences were seen in our field trials. This is because the grower production standards were followed at all sites. Application of routine fungicides in surrounding non-experimental plots may have reduced disease incidence in test pots. However, B. velezensis IALR619 inoculation of strawberry plants indicated that these plants could benefit in the field even under low disease incidences. We had strict reservations with introducing pathogens to the grower fields. Furthermore, much work needs to be done including bacterial applications and dosages in different strawberry cultivars, different soil textures, different application methods, large-scale field trials, bacterial formulation and viability in future commercialization products.

Mechanisms for biological control with bacterial endophytes have been reported. The major factor is antibiotic compounds produced by bacteria to inhibit fungal pathogens. $B$. velezensis is an aerobic, Gram-positive, endospore-forming bacterium that can promote plant growth [36]. It has strain-specific clusters of genes related to the biosynthesis of secondary metabolites for pathogen inhibition and plant growth promotion [30]. For example, it can synthesize cyclic lipopeptides such as surfactin and polyketides such as difficidin [36]. Lipopeptides and polyketides play important roles in the agricultural application by suppressing plant pathogen growth and activating plant defense [37]. From our genomic sequence analysis, we also found gene clusters for secondary metabolite biosynthesis. For example, there are 57 Polyketide synthase modules and related proteins 
and Fe-bacillibactin uptake system FeuA, B, C, etc. (data not shown). In addition, using a Waters I-class UPLC coupled with a TQXS Mass Spectrometer, we detected surfactin and iturin in cultures of IALR585 and IALR619 strains (Table 5).

B. velezensis has received considerable attention because it is a typical plant growthpromoting bacterium as well as a biocontrol agent to control various soil-borne diseases [38] Nam et al. isolated two bacterial strains BS87 and RK1, belonging to B. velezensis, which could control Fusarium wilt of strawberry with better efficacy of RK1 formulation [35]. A commercially available fungicide of B. velezensis, Botrybel (Agricaldes, Spain), is capable of controlling Botrytis cinerea, the etiological agent of gray mold [36].

In summary, B. velezensis IALR619 has potential inhibition of strawberry pathogen growth in the greenhouse and possible ability to increase fruit yield in the field.

Author Contributions: Conceptualization, C.M., S.L. and J.B.S.; methodology, C.M., B.S.A. and J.B.S.; validation, R.L.C., B.S.A., D.L. and G.S.; formal analysis, C.M., J.B.S. and B.S.A.; investigation, R.L.C., B.S.A., D.L. and G.S.; writing-original draft preparation, C.M. and B.S.A.; writing-review and editing, C.M., R.L.C., J.B.S., B.S.A. and S.L.; funding acquisition, C.M., J.B.S. and S.L. All authors have read and agreed to the published version of the manuscript.

Funding: This research was funded by the USDA Specialty Crop Block Grant Program AM170100XXX XG046 and by the Southern Region Small Fruit Consortium Project 2020-R23.

Institutional Review Board Statement: Not applicable.

Informed Consent Statement: Not applicable.

Data Availability Statement: The data presented in this study are available on request from the corresponding author.

Acknowledgments: Authors would like to thank Yimeng He for his analysis of antibiotic compounds from bacterial cultures, and Greenbrier Farms Nursery and Aaron's Creek Farms, Inc. for participating in field trials. The authors appreciate Frank Louws in the Department of Horticultural Science at North Carolina State University for providing Colletotrichum gloeosporioides Cg58 for this research.

Conflicts of Interest: The authors declare no conflict of interest.

\section{References}

1. Shahbandeh, M. Per Capita Consumption of Fresh Strawberries in the United States from 2000 to 2019. U.S. Fresh Strawberries Consumption per Capita 2018 I Statista. 2021. Available online: https://www.statista.com/statistics/823192/us-per-capitaconsumption-of-fresh-strawberries / (accessed on 22 September 2021).

2. Samtani, J.B.; Rom, C.R.; Friedrich, H.; Fennimore, S.A.; Finn, C.E.; Petran, A.; Wallace, R.W.; Pritts, M.P.; Fernandez, G.; Chase, C.A.; et al. The status and future of the strawberry industry in the United States. HortTechnology 2019, 29, 11-24. [CrossRef]

3. Goodhue, R.E.; Fennimore, S.A.; Ajwa, H.A. The economic importance of methyl bromide: Does the California strawberry industry qualify for a critical use exemption from the methyl bromide ban? Appl. Econ. Perspect. Policy 2005, 27, 198-211. [CrossRef]

4. Christman, J.; Samtani, J. A survey of strawberry production practices in Virginia. Va. Coop. Ext. Publ. 2019, SPES-150P, 1-6.

5. Mei, C.; Flinn, B.S. The use of beneficial microbial endophytes for plant biomass and stress tolerance improvement. Recent Pat. Biotechnol. 2010, 4, 81-95. [CrossRef] [PubMed]

6. Glick, B.R. Plant growth-promoting bacteria: Mechanisms and applications. Scientifica 2012, 2012, 963401. [CrossRef] [PubMed]

7. Olanrewaju, O.S.; Glick, B.R.; Babalola, O.O. Mechanisms of action of plant growth promoting bacteria. World J. Microbiol. Biotechnol. 2017, 33, 197. [CrossRef]

8. Afzal, M.; Khan, Q.M.; Sessitsch, A. Endophytic bacteria: Prospects and applications for the phytoremediation of organic pollutants. Chemosphere 2014, 117, 232-242. [CrossRef]

9. Kandel, S.L.; Joubert, P.M.; Doty, S.L. Bacterial endophyte colonization and distribution within plants. Microorganisms 2017, 5, 77. [CrossRef]

10. Compant, S.; Cambon, M.C.; Vacher, C.; Mitter, B.; Samad, A.; Sessitsch, A. The plant endosphere world-bacterial life within plants. Environ. Microbiol. 2021, 23, 1812-1829. [CrossRef]

11. Kim, H.J.; Lee, S.H.; Kim, C.S.; Lim, E.K.; Choi, K.H.; Kong, H.G.; Kim, D.W.; Lee, S.W.; Moon, B.J. Biological control of strawberry gray mold caused by Botrytis cinerea using Bacillus licheniformis N1 formulation. J. Microbiol. Biotechnol. 2007, 17, 438-444.

12. Tortora, M.L.; Díaz-Ricci, J.C.; Pedraza, R.O. Azospirillum brasilense siderophores with antifungal activity against Colletotrichum acutatum. Arch. Microbiol. 2011, 193, 275-286. [CrossRef] [PubMed] 
13. Cha, J.Y.; Han, S.; Hong, H.J.; Cho, H.; Kim, D.; Kwon, Y.; Kwon, S.K.; Crüsemann, M.; Lee, Y.B.; Kim, J.F.; et al. Microbial and biochemical basis of a Fusarium wilt-suppressive soil. ISME J. 2016, 10, 119-129. [CrossRef]

14. Todeschini, V.; AitLahmidi, N.; Mazzucco, E.; Marsano, F.; Gosetti, F.; Robotti, E.; Bona, E.; Massa, N.; Bonneau, L.; Marengo, E.; et al. Impact of beneficial microorganisms on strawberry growth, fruit production, nutritional quality, and volatilome. Front. Plant Sci. 2018, 9, 1611. [CrossRef]

15. de Andrade, F.M.; de Assis Pereira, T.; Souza, T.P.; Guimarães, P.H.; Martins, A.D.; Schwan, R.F.; Pasqual, M.; Dória, J. Beneficial effects of inoculation of growth-promoting bacteria in strawberry. Microbiol. Res. 2019, 223, 120-128. [CrossRef] [PubMed]

16. Chen, X.H.; Vater, J.; Piel, J.; Franke, P.; Scholz, R.; Schneider, K.; Koumoutsi, A.; Hitzeroth, G.; Grammel, N.; Strittmatter, A.W.; et al. Structural and functional characterization of three polyketide synthase gene clusters in Bacillus amyloliquefaciens FZB 42. J. Bacteriol. 2006, 188, 4024-4036. [CrossRef] [PubMed]

17. Mei, C.; Chretien, R.L.; Amaradasa, B.S.; He, Y.; Turner, A.; Lowman, S. Characterization of phosphate solubilizing bacterial endophytes and plant growth promotion in vitro and in greenhouse. Microorganisms 2021, 9, 1935. [CrossRef]

18. Kim-Dura, S.; Lowman, S.; Zhang, S.; Mei, C. Growth promotion of switchgrass by bacterial endophyte Pantoea agglomerans strain PaKM isolated from seeds. J. Pathol. Microbiol. 2016, 1, 1-9.

19. Patten, C.L.; Glick, B.R. Role of Pseudomonas putida indoleacetic acid in development of the host plant root system. Appl. Environ. Microbiol. 2002, 68, 3795-3801. [CrossRef] [PubMed]

20. Murphy, J.A.; Riley, J.P. A modified single solution method for the determination of phosphate in natural waters. Anal. Chim. Acta 1962, 27, 31-36. [CrossRef]

21. Bolger, A.M.; Lohse, M.; Usadel, B. Trimmomatic: A flexible trimmer for Illumina sequence data. Bioinformatics 2014, 30, 2114-2120. [CrossRef]

22. Zerbino, D.R.; Birney, E. Velvet: Algorithms for de novo short read assembly using de Bruijn graphs. Genome Res. 2008, 18, 821-829. [CrossRef] [PubMed]

23. Hyatt, D.; Chen, G.; Locascio, P.; Land, M.; Larimer, F.; Hauser, L. BMC bioinformatics [electronic resource]. BMC Bioinform. 2010, 11, 119.

24. Chan, P.P.; Lowe, T.M. tRNAscan-SE: Searching for tRNA genes in genomic sequences. In Gene Prediction; Humana: New York, NY, USA, 2019; pp. 1-14.

25. Darling, A.E.; Mau, B.; Perna, N.T. progressiveMauve: Multiple genome alignment with gene gain, loss and rearrangement. PLoS ONE 2010, 5, e11147. [CrossRef] [PubMed]

26. Aziz, R.K.; Bartels, D.; Best, A.A.; DeJongh, M.; Disz, T.; Edwards, R.A.; Formsma, K.; Gerdes, S.; Glass, E.M.; Kubal, M.; et al. The RAST Server: Rapid annotations using subsystems technology. BMC Genom. 2008, 9, 75. [CrossRef] [PubMed]

27. Emms, D.M.; Kelly, S. OrthoFinder: Solving fundamental biases in whole genome comparisons dramatically improves orthogroup inference accuracy. Genome Biol. 2015, 16, 157. [CrossRef] [PubMed]

28. Emms, D.M.; Kelly, S. STAG: Species tree inference from all genes. BioRxiv 2018, 267914. [CrossRef]

29. Emms, D.M.; Kelly, S. STRIDE: Species tree root inference from gene duplication events. Mol. Biol. Evol. 2017, 34, 3267-3278. [CrossRef] [PubMed]

30. Kim, S.Y.; Lee, S.Y.; Weon, H.Y.; Sang, M.K.; Song, J. Complete genome sequence of Bacillus velezensis M75, a biocontrol agent against fungal plant pathogens, isolated from cotton waste. J. Biotechnol. 2017, 241, 112-115. [CrossRef]

31. Pastrana, A.M.; Basallote-Ureba, M.J.; Aguado, A.; Akdi, K.; Capote, N. Biological control of strawberry soilborne pathogens Macrophomina phaseolina and Fusarium solani, using Trichoderma asperellum and Bacillus spp. Phytopathol. Mediterr. 2016, 1, 109-120.

32. Khalil, S.; Svensson, B. Biological control of root pathogens in strawberry cultivation in tunnel. In VIII International Strawberry Symposium; ISHS Acta Horticulturae: Québec City, Canada, 2016; pp. 811-816.

33. Marian, M.; Ohno, T.; Suzuki, H.; Kitamura, H.; Kuroda, K.; Shimizu, M. A novel strain of endophytic Streptomyces for the biocontrol of strawberry anthracnose caused by Glomerella cingulata. Microbiol. Res. 2020, 234, 126428. [CrossRef]

34. Bona, E.; Lingua, G.; Manassero, P.; Cantamessa, S.; Marsano, F.; Todeschini, V.; Copetta, A.; D’Agostino, G.; Massa, N.; Avidano, L.; et al. AM fungi and PGP pseudomonads increase flowering, fruit production, and vitamin content in strawberry grown at low nitrogen and phosphorus levels. Mycorrhiza 2015, 25, 181-193. [CrossRef] [PubMed]

35. Nam, M.H.; Park, M.S.; Kim, H.G.; Yoo, S.J. Biological control of strawberry Fusarium wilt caused by Fusarium oxysporum f. sp. fragariae using Bacillus velezensis BS87 and RK1 formulation. J. Microbiol. Biotechnol. 2009, 19, 520-524. [CrossRef] [PubMed]

36. Rabbee, M.F.; Ali, M.D.; Choi, J.; Hwang, B.S.; Jeong, S.C.; Baek, K.H. Bacillus velezensis: A valuable member of bioactive molecules within plant microbiomes. Molecules 2019, 24, 1046. [CrossRef]

37. Aleti, G.; Sessitsch, A.; Brader, G. Genome mining: Prediction of lipopeptides and polyketides from Bacillus and related Firmicutes. Comput. Struct. Biotechnol. J. 2015, 13, 192-203. [CrossRef] [PubMed]

38. Cawoy, H.; Bettiol, W.; Fickers, P.; Ongena, M. Bacillus-based biological control of plant diseases. In Pesticides in the Modern World-Pesticides Use and Management; Stoytcheva, M., Ed.; IntechOpen: London, UK, 2011; pp. 273-302. 